\title{
PERANCANGAN INFRASTRUKTUR TEKNOLOGI INFORMASI ADAPTIF PADA BADAN TENAGA NUKLIR NASIONAL
}

\author{
Dewi Hernikawati ${ }^{1}$, Yan Andriariza Ambhita Sukma ${ }^{2}$, Nur Indrawati ${ }^{3}$, Yulia Razila Ningsih ${ }^{4}$ \\ ${ }^{1}$ BPPKI Jakarta, Jl. Pegangsaan Timur No. 19 B, Jakarta Pusat \\ ${ }^{2}$ Puslitbang Aptika IKP, Jl. Medan Merdeka Barat No. 9, Jakarta Pusat \\ ${ }^{3}$ Kementerian Komunikasi dan Informatika, Jl. Medan Merdeka Barat No. 17, Jakarta Pusat \\ ${ }^{4}$ Pemerintah Provinsi Riau, Jl. Jendral Sudirman Kompleks Kantor Gubernur \\ No. Telp/ HP : ${ }^{1} 08158762573,{ }^{2} 08164246595,{ }^{3} 085221455415,{ }^{4} 0811753021$ \\ E-mail : ${ }^{1}$ dewi005@kominfo.go.id, ${ }^{2}$ andriariza@gmail.com, ${ }^{3}$ nurindrawati@gmail.com, \\ 4yulia.razila@gmail.com
}

\section{DESIGN AN ADAPTIVE INFORMATION TECHNOLOGY INFRASTRUCTURE AT NATIONAL NUCLEAR ENERGY AGENCY OF INDONESIA}

\begin{abstract}
Design an adaptive IT infrastructure in BATAN is needed to solve problems related to research and partnerships, which is the main function of BATAN. This research uses TOGAF ADM framework. Result of this research is a design of an adaptive IT infrastructureat BATAN. The results of research, there are fives applications were retained and fives applications were replaced. There are additional applications and infrastructure: SIPO, SIKO, and SOAP.
\end{abstract}

Keywords: BATAN, adaptive infrastructure, TOGAF ADM.

\begin{abstract}
Abstrak. Perancangan infrastruktur TI adaptif pada Badan Tenaga Nuklir Nasional (BATAN) dipandang perlu dilakukan untuk mengatasi permasalahan terkait penelitian dan kemitraan yang merupakan fungsi utama BATAN. Penelitian ini menggunakan kerangka kerja The Open Group Architecture Framework Architecture Development Method (TOGAF ADM). Penelitian ini menghasilkan rancangan infrastruktur Teknologi Informasi adaptif di Badan Tenaga Nuklir Nasional (BATAN). Hasil penelitian yaitu terdapat lima aplikasi yang dipertahankan dan lima aplikasi yang diganti. Terdapat aplikasi dan infrastruktur tambahan, yaitu: Sistem Informasi Penelitian Online (SIPO), Sistem Informasi Kemitraan Online (SIKO), dan Simple Object Acsess Protocol (SOAP).
\end{abstract}

Kata kunci: BATAN, infrastruktur adaptif, TOGAF ADM.

\section{PENDAHULUAN}

Badan Tenaga Nuklir Nasional (BATAN) merupakan salah satu Lembaga Pemerintah Non-Kementerian (LPNK). Tujuan BATAN, sesuai dengan Rencana Strategis BATAN 2015-2019, adalah terwujudnya BATAN sebagai lembaga unggulan iptek nuklir di tingkat regional; dan peningkatan peran iptek nuklir dalam mendukung pembangunan nasional menuju kemandirian bangsa. Namun, dalam mencapai tujuan tersebut, terdapat beberapa permasalahan yang masih belum terselesaikan. 
Permasalahan-permasalahan tersebut antara lain tumpang tindih tema/topik/judul penelitian yang dilakukan, informasi mengenai status proposal/penelitian kepada para peneliti internal BATAN lambat diperoleh, jadwal pelaksanaan tahapan penelitian tidak disebutkan dengan jelas, serta belum terintegrasinya sistem informasi/aplikasi nuklir sehingga peneliti BATAN masih kesulitan mendapatkan informasi terkait penelitian nuklir. Selain itu, mitra BATAN kesulitan dalam mendapatkan informasi penelitian di BATAN, sehingga kerjasama dengan mitra menjadi kurang optimal.

Infrastruktur teknologi informasi saat ini (data tahun 2012) masih belum adaptif dalam menjawab kebutuhan bisnis organisasi. Sebagai contoh, jumlah kegiatan penelitian pada Pusat Teknologi Radioisotop dan Radiofarmaka BATAN sebanyak dua belas kegiatan penelitian per tahun, dengan total dana yang diperlukan sebesar 2,6 miliar rupiah. Sehingga opportunity loss penelitian pada Pusat Teknologi Radioisotop dan Radiofarmaka mencapai 2,6 miliar rupiah per tahun, apabila penelitian-penelitian tersebut tidak mendapatkan pendanaan (Kasim, 1995).

$$
\text { Penelitian ini membahas }
$$

perancangan infrastruktur teknologi informasi adaptif pada BATAN dengan menggunakan kerangka kerja The Open Group Architecture Framework Architecture Development Method (TOGAF ADM).

Fase pada penelitian ini dibatasi hanya enam fase awal dari TOGAF ADM, yang mencakup: preliminary, architecture vision, business architecture, information systems architectures, technology architecture, opportunities and solutions. Dengan adanya penelitian ini diharapkan dapat memberikan rancangan infrastruktur teknologi informasi adaptif yang sesuai dengan kebutuhan bisnis BATAN.

Permasalahannya adalah bagaimana rancangan infrastruktur teknologi informasi adaptif yang sesuai dengan kebutuhan bisnis Badan Tenaga Nuklir
Nasional (BATAN)? Penelitian ini bertujuan untuk merancang infrastruktur teknologi informasi adaptif pada BATAN. Perancangan infrastruktur teknologi informasi pada penelitian ini dilakukan sesuai dengan kerangka kerja TOGAF ADM yang dibatasi pada enam fase, yaitu preliminary, architecture vision, business architecture, information systems architectures, technology architecture, dan opportunities and solutions.

\section{LANDASAN KONSEP}

\section{Penelitian Sebelumnya}

Terdapat beberapa penelitian terkait perancangan infrastruktur TI. Penelitian "Perencanaan Arsitektur Enterprise Menggunakan Metode TOGAF ADM" Kustiyahningsih (2013) menghasilkan Arsitektur Enterprise rumah sakit yang standar berdasarkan perencanaan informasi strategis dan integrasi sistem. Penelitian ini menggunakan metodologi TOGAF. Hasil penelitian ini berupa cetak biru TI yang didasarkan pada perencanaan jangka pendek dan jangka panjang (roadmap) TOGAF yang telah dibuat sehingga menghasilkan sistem yang terintegrasi, guna menjawab kebutuhan fungsi pelayanan khususnya dibidang kesehatan.

Penelitian Solichin and Hasibuan (2012) ditujukan untuk merancang suatu model arsitektur Teknologi Informasi menggunakan konsep cloud computing. Berdasarkan hasil analisis dengan menggunakan TOGAF, cloud computing merupakan teknologi yang sesuai dengan kondisi dan kebutuhan perguruan tinggi di Indonesia. Penelitian Anggrainingsih et al. (2013) menggunakan pendekatan TOGAF ADM untuk memodelkan bisnis proses dengan menggunakan BPMN, terkait administrasi mahasiswa yang ideal untuk Universitas Sebelas Maret. Penelitian Wibowo et al. (2013) memfokuskan pada bagaimana merancang integrasi sistem model aplikasi yang tersedia sebagai suatu sistem yang terintegrasi yang mengotomasi 
penilaian dan pengajuan nilai kredit auditor pada Badan Pemeriksa Keuangan.

Penelitian

"Perancangan

Infrastruktur Jaringan Komputer dalam Konsep Membangun Serang Menuju Smartcity" menghasilkan rancangan infrastruktur jaringan smartcity di Kota Serang menggunakan kerangka kerja Zachman (Rosalina et al., 2014). Hasil penelitian berupa cetak biru rancangan infrastruktur jaringan komputer yang dipetakan dalam bentuk matrik "where" pada kerangka kerja Zachman, ditinjau dari sudut pandang planner dan owner (Rosalina et al., 2014). Diperoleh informasi detail tentang rancangan jaringan komputer, sehingga pada akhirnya dapat digunakan oleh Pemerintah Kota Serang dalam mewujudkan smartcity (Rosalina et al., 2014).

\section{Arsitektur Teknologi Informasi}

Dalam TOGAF (The Open Group Architecture Forum, 2011) arsitektur memiliki dua makna, yaitu (1) deskripsi formal dari sistem atau rencana detail dari sistem pada level komponen untuk memandu implementasinya; dan (2) struktur komponen, dan relasionalnya, dan prinsip serta panduan tata kelola desain dan evolusinya. ITIL (The Stationery Office, 2011) mendefinisikan arsitektur teknologi informasi sebagai keseluruhan aspek yang meliputi perangkat keras, perangkat lunak, perangkat jaringan dan fasilitas-fasilitas lainnya yang diperlukan untuk pengembangan, ujicoba, pengaturan, dan daya dukung terhadap aplikasi dan layanan teknologi informasi.

\section{TOGAF ADM}

TOGAF mendukung 4 (empat) domain arsitektur, yaitu: bisnis, data, aplikasi, dan teknologi. Arsitektur bisnis mendefinisikan strategi bisnis, tata kelola, dan proses bisnis utama. Arsitektur data, mendeskripsikan aset data logic dan fisik, serta pengelolaan data. Arsitektur aplikasi menyediakan cetak biru sistem aplikasi yang diterapkan, interaksinya, dan relasinya dengan proses bisnis organisasi. Arsitektur teknologi mendeskripsikan kapasitas logic perangkat keras dan perangkat lunak yang dipersyaratkan untuk mendukung penerapan layanan bisnis, data, dan aplikasi. Arsitektur teknologi mencakup infrastruktur, middleware, proses, standar. TOGAF merupakan sebuah kerangka kerja pengembangan arsitektur teknologi informasi korporasi, yang menyediakan sebuah klasifikasi untuk menghubungkan konsep-konsep yang menggambarkan dunia nyata pada konsepkonsep yang menggambarkan Sistem Informasi dan implementasinya.

TOGAF ADM menyediakan proses berulang pengembangan arsitektur Teknologi Informasi ADM yang mencakup pembangunan kerangka kerja arsitektur, pembangunan konten arsitektur, transisi, dan tata kelola arsitektur. Seluruh aktivitas pengembangan arsitektur dilakukan dalam suatu siklus interaktif dari pendefinisian dan realisasi arsitektur berkesinambungan. Fase-fase dalam ADM, yaitu: fase preliminary, fase architecture vision, fase business architecture, fase information systems architectures, fase technology architectures, fase opportunities and solutions, fase migration planning, fase implementation governance, fase architecture change management, dan fase requirements management.

\section{Perancangan Infrastruktur Teknologi Informasi Adaptif}

Infrastruktur Teknologi Informasi (TI) adaptif (Robertson and Sribar, 2002) disusun dengan menggunakan pola tertentu untuk mendukung penerapan Teknologi Informasi dan mudah disesuaikan dengan kondisi. Manifestasi dari infrastruktur TI adaptif adalah:

1. Efficiency, dengan tersedianya komponen-komponen yang dapat dimanfaatkan bersama oleh berbagai sistem aplikasi (lama dan baru); 
2. Effectiveness, menggunakan komponenkomponen yang mudah dipadukan (interoperable) dan diintegrasikan;

3. Agility, dengan komponen-komponen yang mudah dirombak, di-upgrade, atau diganti.

4. Tolak ukur dari adaptiveness infrastruktur TI, yaitu: time to market (kecepatan dalam implementasi layanan baru); scalibility (mampu mengakomodasi peningkatan penggunaan/beban); extensibility (kemudahan menambah komponen baru); complexity partitioning (partisi arsitektur aplikasi kedalam komponenkomponen yang dapat dikelola secara terpisah (modular)); reusability (pemanfaatan ulang atau pemanfaatan silang komponen-komponen infrastruktur oleh berbagai layanan TI organisasi; dan integration (pemanfaatan teknologi open standar yang memungkinkan integrasi antar komponen infrastruktur).

\section{METODE PENELITIAN}

Pengumpulan data untuk penelitian ini dilakukan melalui wawancara dengan pegawai yang kompeten di lingkungan BATAN, dan studi literatur dokumen formal organisasi BATAN. Analisis data dalam penelitian ini menggunakan metode kualitatif melalui studi literatur dan hasil wawancara.

\section{Kerangka Penelitian}

Kerangka pikir penelitian dapat dilihat pada gambar 1. Sesuai dengan Peraturan Pemerintah No. 46 Tahun 2013, BATAN menjalankan fungsi penelitian dan kemitraan. Selanjutnya, dilakukan studi terhadap rencana strategis BATAN. Berdasarkan data yang diperoleh, diidentifikasi strategi bisnis dan program kerja BATAN. Kemudian disusun portofolio aplikasi, dan rancangan infrastruktur adaptif sesuai kerangka kerja TOGAF ADM.

\section{HASIL PENELITIAN DAN PEMBAHASAN}

\section{Analisis Proses Bisnis}

Gambar 1 menunjukkan fungsi BATAN. Fungsi utama, yaitu penelitian, diseminasi, kemitraan, dan pengembangan Teknologi Informasi. Fungsi pendukung yaitu perencanaan dan evaluasi program, penyusunan anggaran, pengembangan SDM, administrasi kepegawaian, pembinaan dan pengelolaan keuangan serta sarana dan prasarana, standardisasi dan peningkatan jaringan kelembagaan IPTEK nuklir, penyelenggaraan pengawasan, pemeriksaan, penyelenggaraan pendidikan dan pelatihan.

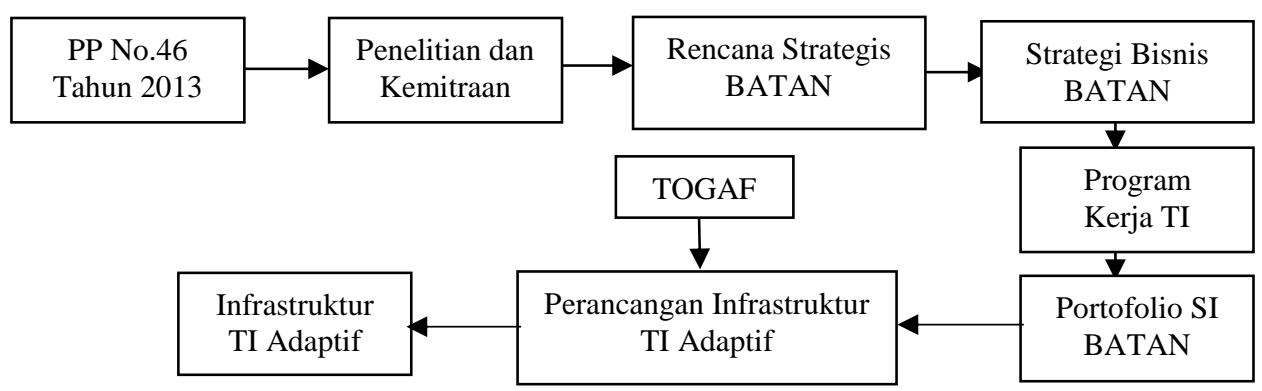

Gambar 1. Kerangka Pikir Penelitian 


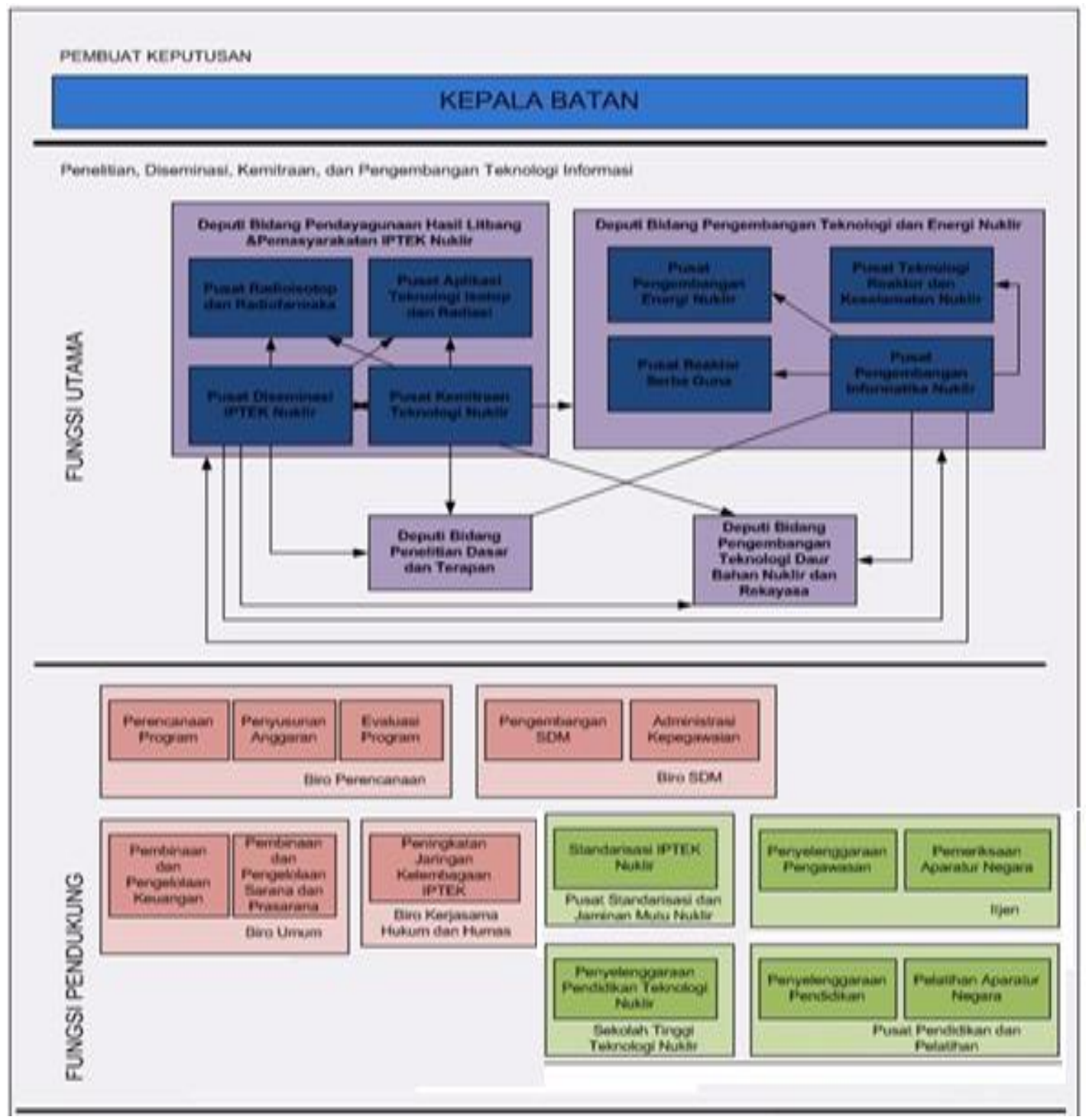

Gambar 2. Hasil Analisis Proses Bisnis BATAN

Identifikasi Permasalahan, Strategi, dan Konsep Solusi Teknologi Informasi

Permasalahan SI/TI yang teridentifikasi pada BATAN, salah satunya adalah sistem informasi/aplikasi nuklir yang belum terintegrasi. Belum terintegrasinya SI/aplikasi ini dapat menyebabkan pemakaian infrastruktur kurang efisien. Selain itu, masih terdapat tumpang tindih tema/topik/judul penelitian yang dilakukan, mitra BATAN sulit mendapatkan informasi penelitian di BATAN sehingga terkendala masalah Pendanaan penelitian, waktu yang lama dalam pelaksanaan penelitian sehingga tidak dapat dipastikan kapan penelitian selesai, dan BATAN tidak/lambat dalam memberikan informasi mengenai status proposal/penelitian kepada para peneliti di internal BATAN. Hasil identifikasi permasalahan dan strategi TI (tolak ukur dan sasaran perbaikan) pada BATAN dapat dilihat pada tabel 1. Sasaran perbaikan sesuai dengan strategi Business Process Reengineering (BPR). Salah satu sasaran perbaikan adalah integrasi data dan membangun pusat data. 
Tabel 1

Portofolio Aplikasi SI/TI pada BATAN

\begin{tabular}{ll}
\hline \multicolumn{1}{c}{ Permasalahan } & \multicolumn{1}{c}{ Tolak Ukur } \\
\hline $\begin{array}{l}\text { Sistem } \\
\text { Informasi/aplikasi nuklir } \\
\text { belum terintegrasi. }\end{array}$ & $\begin{array}{l}\text { Jumlah sistem informasi/ap } \\
\text { nuklir yang terintegrasi. }\end{array}$ \\
$\begin{array}{l}\text { Tumpang tindih } \\
\text { tema/topik/judul } \\
\text { penelitian yang }\end{array}$ & Jumlah Penelitian dengan \\
& judul/tema yang sama.
\end{tabular}

penelitian yang

dilakukan.

si/aplikasi

Sasaran Perbaikan

Integrasi data dari berbagai sumber dalam

organisasi (analyze and synthesize, collect, connect, create).

Input data dari beberapa tempat, disimpan pada satu data center, dan didistribusikan ke seluruh unit kerja di BATAN (mass customize, sensitize, digitize and propragate, analyze and synthesize; connect, collect and create).

Mitra BATAN sulit mendapatkan informasi penelitian di BATAN, sehingga terkendala masalah pendanaan penelitian.

Waktu yang lama dalam pelaksanaan penelitian.

BATAN tidak/lambat dalam memberikan informasi mengenai status proposal/penelitian kepada para peneliti di internal BATAN.
Jumlah mitra BATAN yang terhubung/terintegrasi ke sistem Informasi BATAN.

Lamanya waktu dari pengajuan proposal sampai dengan laporan hasil penelitian.

Jumlah peneliti yang mengetahui status dan perkembangan penelitian.
Integrasi sistem informasi/aplikasi mitra, penyediaan informasi tentang penelitian yang dilakukan BATAN (mass customize, synchronize, analyze and synthesize)
Memetakan peneliti sesuai dengan kompetensinya (minimasi waktu menunggu tahap penelitian (loosewait), membagi pekerjaan berdasarkan kompetensi peneliti (orchestra), analyze and synthesize).

Menyediakan informasi tentang penelitian, salah satunya status penelitian ke seluruh peneliti di BATAN (mass customize; synchronize; digitize and propagate, verify; analyze and synthesize; connect, collect and create)

Sumber: Hasil Penelitian

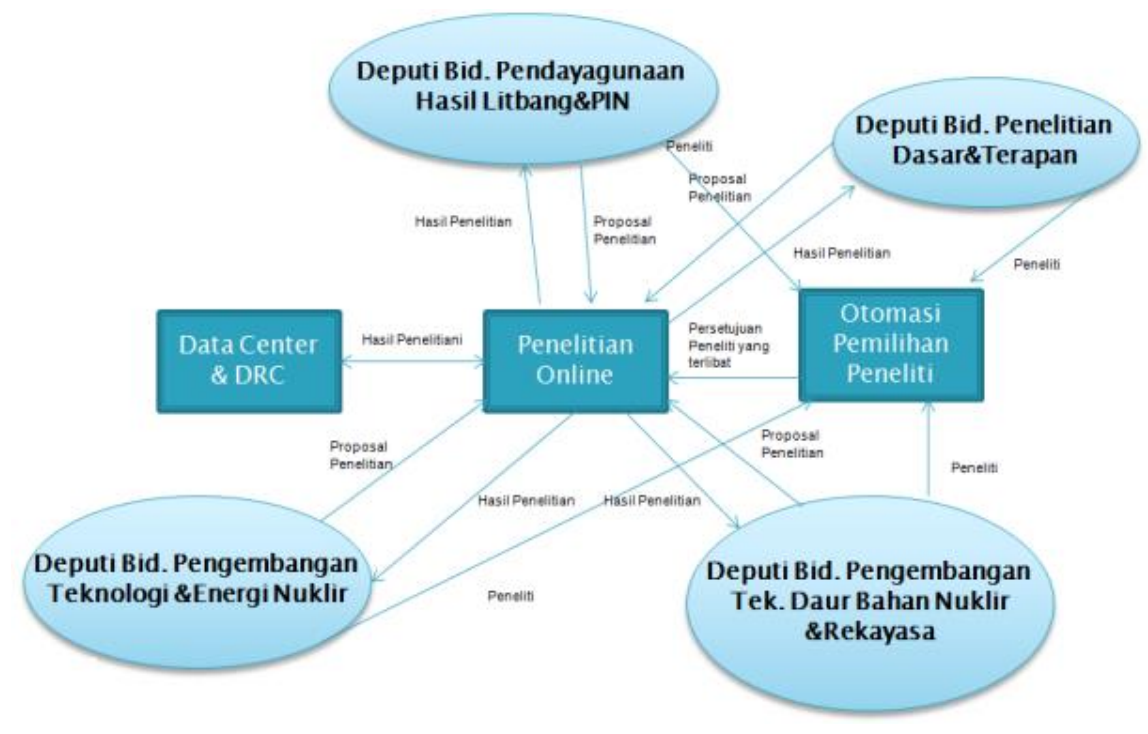

Gambar 3. Critical Proces Penelitian 


\begin{tabular}{|l|}
\hline \multicolumn{1}{|c|}{ Pola Solusi } \\
\hline $\begin{array}{l}\text { Sistem informasi terintegrasi } \\
\text { dilengkapi dengan data center dan DRC } \\
\text { yang update untuk menyimpan data } \\
\text { organisasi }\end{array}$ \\
\hline $\begin{array}{l}\text { Sistem aplikasi online terintegrasi } \\
\text { untuk mendukung aktivitas penelitian } \\
\text { (misal: otomasi proses persetujuan } \\
\text { penelitian) didukung dengan database } \\
\text { penelitian yang terintegrasi dalam } \\
\text { DC\&DRC }\end{array}$ \\
\hline $\begin{array}{l}\text { Sistem aplikasi kemitraan online } \\
\text { terintegrasi untuk memberikan } \\
\text { informasi penelitian / pertukaran data } \\
\text { dengan mitra }\end{array}$ \\
\hline $\begin{array}{l}\text { Fasilitas pemilihan peneliti : kesamaan } \\
\text { judul/topik/tema penelitian, waktu } \\
\text { penelitian dan kompetensi peneliti }\end{array}$ \\
\hline $\begin{array}{l}\text { Sistem aplikasi online terintegrasi } \\
\text { untuk mendukung penelitian (berkas } \\
\text { dan status penelitian) didukung } \\
\text { dengan database penelitian yang } \\
\text { terintegrasi dalam DC\&DRC }\end{array}$ \\
\hline
\end{tabular}

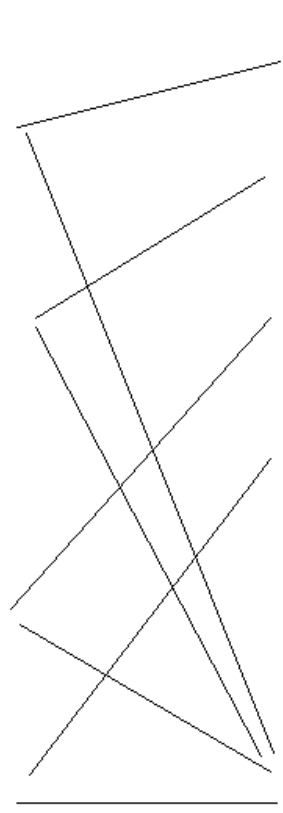

-Pertukaran data antar organisasi harus menggunakan format yang sama

- Akomodasi field data secara dinamis

-Minimasi dampak perubahan protokol

-Interoperabilitas antar sistem

informasi

-Publikasi data yang sesuai dengan

penerima informasi

-enkripsi data (minimal SSL)

-menggunakan firewall

- data disimpan di DC/DRC

-ERP untuk untuk integrasi aplikasi

penelitian dan kemitraan

Aplikasi layanan masyarakat dapat diakses melalui internet, dan dapat diakses oleh pihak-pihak yang berhak dan berkepentingan.

Gambar 4. Prinsip-Prinsip Penerapan TI pada BATAN

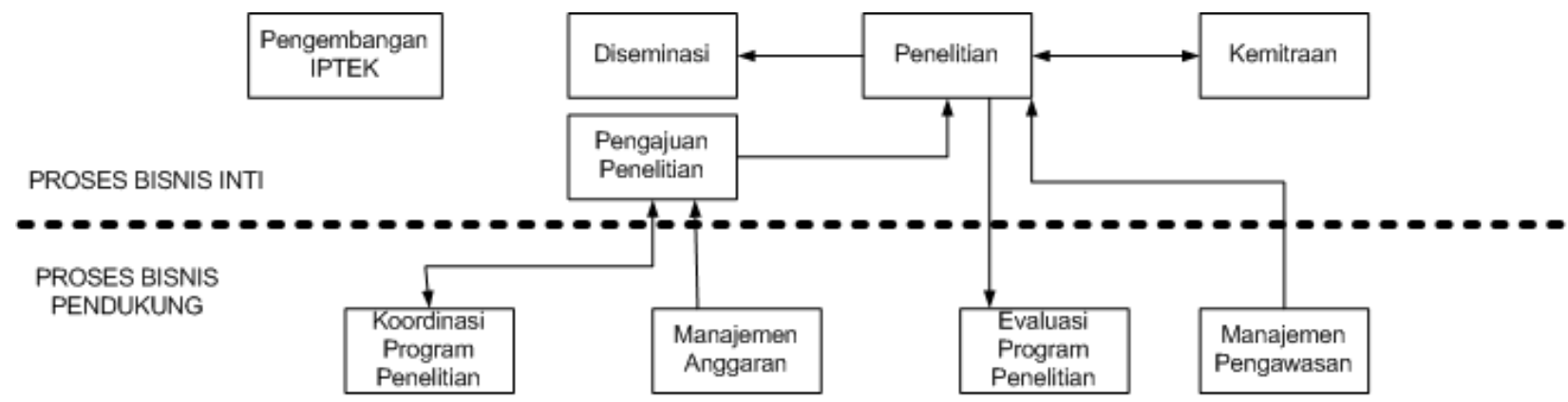

\begin{tabular}{|c|c|}
\hline $\begin{array}{c}\text { Manajemen } \\
\text { Sarana dan } \\
\text { Prasarana }\end{array}$ & $\begin{array}{c}\text { Manajemen } \\
\text { Kepegawaian }\end{array}$ \\
\hline $\begin{array}{c}\text { Pendidikan } \\
\text { Masyarakat }\end{array}$ & $\begin{array}{c}\text { Pelatihan } \\
\text { Pegawai }\end{array}$ \\
\hline
\end{tabular}

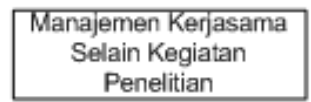

Manajemen

Standarisas

Gambar 5. Pemodelan Proses Bisnis BATAN

\section{Visi Arsitektur Teknologi Informasi}

Pola solusi dan prinsip-prinsip arsitektur TI dapat dilihat pada gambar 4. Perancangan arsitektur TI dipandu oleh prinsip-prinsip yang diturunkan dari konsep solusi TI strategis untuk memastikan bahwa teknologi yang diimplementasikan dapat mendukung dan selaras dengan solusi strategis. Prinsipprinsip arsitektur juga mempertimbangkan kondisi TI organisasi saat ini (data tahun
2012), mengutamakan pemanfaatan asetaset TI yang sudah dimiliki, dan meminimasi risiko migrasi.

\section{Arsitektur Bisnis Organisasi}

Pada gambar 5 dapat dilihat pemodelan proses bisnis BATAN. Proses bisnis inti BATAN yaitu pengembangan IPTEK, diseminasi, penelitian, kemitraan, dan pengajuan penelitian. 
Proses bisnis pendukung yaitu koordinasi program penelitian, manajemen anggaran, evaluasi program penelitian, manajemen pengawasan, manajemen sarana dan prasarana, manajemen kepegawaian, manajemen kerjasama selain

kegiatan penelitian, manajemen standardisasi, pendidikan masyarakat, dan pelatihan pegawai. Data Flow Diagram (DFD) Level 1 untuk masing-masing proses bisnis kritis, dapat dilihat pada gambar 6 dan gambar 7.

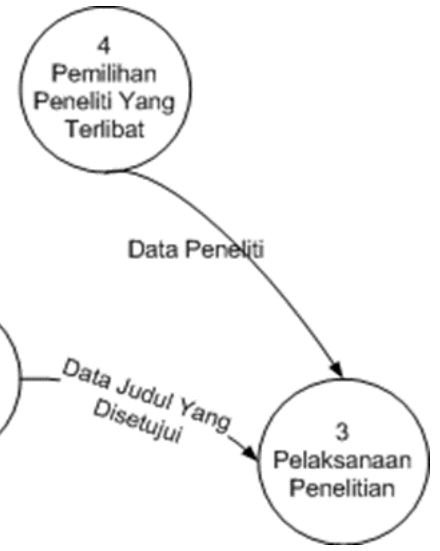

Gambar 6. Data Flow Diagram (DFD) Level Proses Penelitian

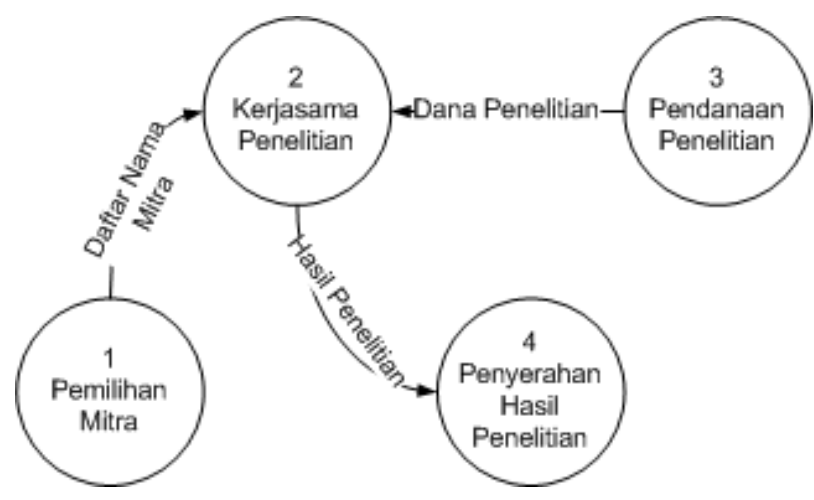

Gambar 7. Data Flow Diagram (DFD) Level 1 Proses Kemitraan

Proses penelitian diawali dengan pengajuan proposal penelitian. Berdasarkan data judul penelitian, dilakukan proses pemeriksaan dan persetujuan proposal.

Untuk menentukan peneliti yang terlibat, dilakukan secara online melalui proses pemilihan peneliti. Judul penelitian yang sudah disetujui kemudian dilaksanakan penelitiannya.

Proses kemitraan diawali dengan pemilihan mitra penelitian. Mitra terpilih kemudian dilibatkan dalam (kerjasama) penelitian. Hasil penelitian yang sudah dilakukan diserahkan secara online.

\section{Arsitektur Sistem Informasi}

Identifikasi aplikasi kunci pada BATAN menghasilkan beberapa solusi/paket solusi. Solusi/paket solusi yang teridentifikasi, yaitu: sistem informasi penelitian online, kemitraan online, sistem informasi manajemen kepegawaian, sistem informasi manajemen keuangan, dan Enterprise Resource Planning (ERP).

Aplikasi sistem informasi tersebut merupakan solusi terintegrasi, yang dilengkapi dengan DC/DRC untuk mendukung kegiatan pelayanan di BATAN. Hasil identifikasi aplikasi kunci pada BATAN dapat dilihat pada tabel 2 berikut. 
Tabel 2

Portofolio Aplikasi SI/TI pada BATAN

\section{Pola Solus}

Sistem informasi terintegrasi dilengkapi dengan data center dan DRC yang update untuk menyimpan data organisasi.

Sistem aplikasi online terintegrasi untuk mendukung aktivitas penelitian (misal otomasi proses persetujuan penelitian) didukung dengan database penelitian yang terintegrasi dalam DC/DRC.

Sistem aplikasi kemitraan online terintegrasi untuk memberikan informasi penelitian/pertukaran data dengan mitra.

Fasilitas pemilihan peneliti: kesamaan judul/topik/tema penelitian, waktu penelitian dan kompetensi peneliti.

Sistem aplikasi online terintegrasi untuk mendukung penelitian (berkas dan status penelitian) didukung dengan database penelitian yang terintegrasi dalam DC \& DRC.
Sistem Informasi Penelitian Online saat ini (data tahun 2012), SIM Kepegawaian, SIM Keuangan, ERP (usulan)

Sistem Informasi Penelitian Online, ERP (usulan)

Sistem Informasi Kemitraan Online, ERP (usulan)

Sistem Informasi Penelitian Online, ERP (usulan)

Sistem Informasi Penelitian Online, ERP (usulan)

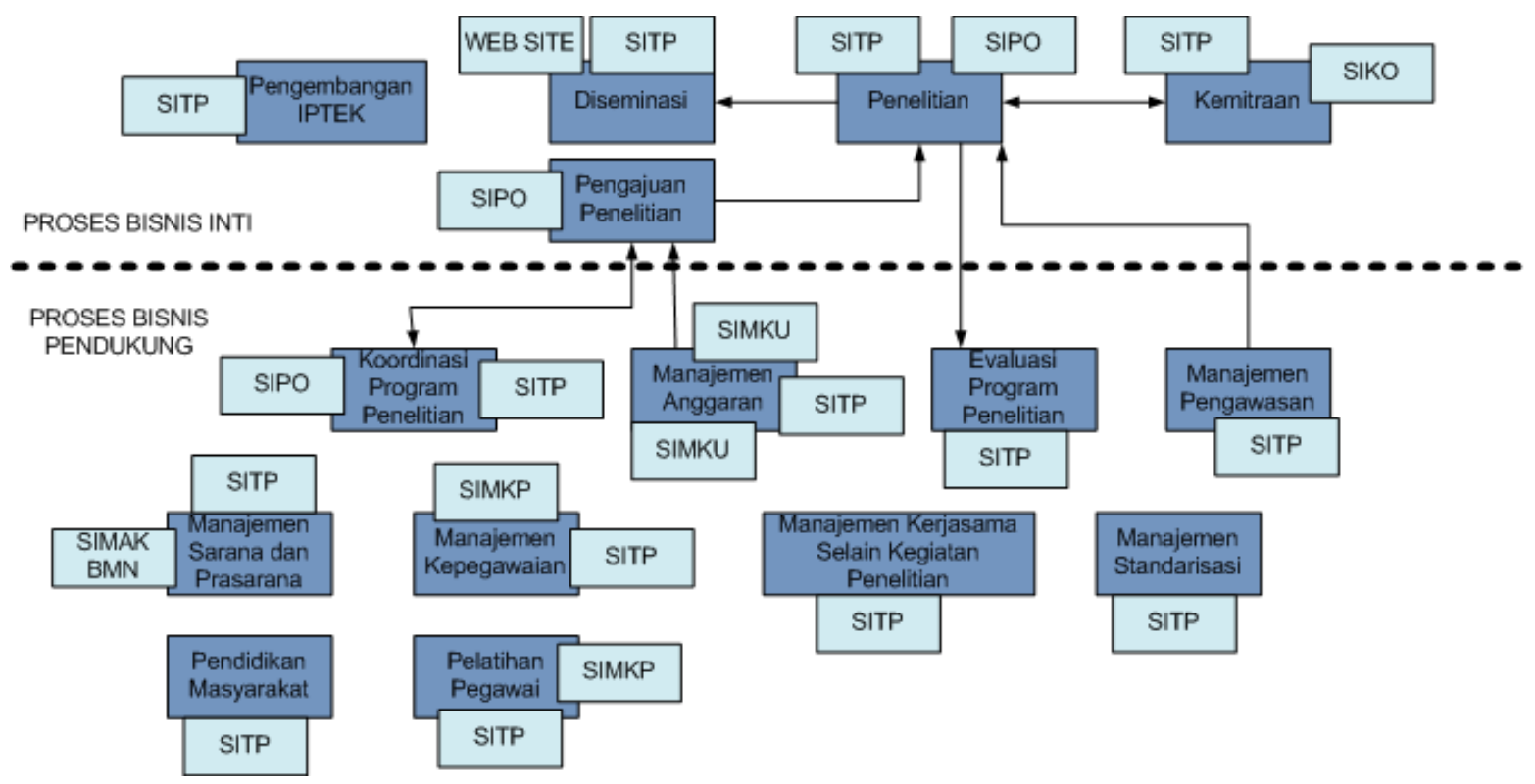

Gambar 8. Pemetaan Aliran Informasi BATAN

Gambar 8 menunjukkan pemetaan aliran informasi pada BATAN. SITP digunakan dalam proses bisnis inti dan pendukung pengembangan IPTEK, diseminasi, penelitian, kemitraan, manajemen sarana dan prasarana, koordinasi program penelitian, manajemen anggaran, evaluasi program penelitian, manajemen pengawasan, manajemen standardisasi, manajemen sarana dan prasarana, pendidikan masyarakat, pelatihan pegawai, dan manajemen kerjasama selain kegiatan penelitian. SIPO digunakan dalam proses bisnis inti dan pendukung untuk penelitian, dan koordinasi program penelitian. SIKO digunakan dalam mengelola kemitraan.

Selain itu, terdapat beberapa aplikasi SI lainnya yang disarankan digunakan di lingkungan BATAN. Keterangan fungsionalitas aplikasi dapat dilihat pada tabel 3 . 
Tabel 3

Portofolio Aplikasi SI/TI pada BATAN

\begin{tabular}{|c|c|c|}
\hline Kode & Nama & Poin Kolom 2 \\
\hline SIKO & $\begin{array}{l}\text { Sistem Informasi } \\
\text { Kemitraan Online }\end{array}$ & $\begin{array}{l}\text { Mengelola hubungan dengan mitra, pertukaran } \\
\text { data/informasi penelitian dengan mitra. }\end{array}$ \\
\hline SIPO & $\begin{array}{l}\text { Sistem Informasi } \\
\text { Penelitian Online }\end{array}$ & $\begin{array}{l}\text { Trace dan tracking berkas dan status } \\
\text { penelitian, peneliti yang terlibat, perencanaan } \\
\text { kegiatan. }\end{array}$ \\
\hline SIMKP & $\begin{array}{l}\text { Sistem Informasi } \\
\text { Manajemen Kepegawaian }\end{array}$ & $\begin{array}{l}\text { Mengelola data pegawai, berisi } \mathrm{CV} \text {, aktivitas } \\
\text { fungsional, laporan, tabel referensi, absensi, } \\
\text { pelatihan dan pendaftaran. }\end{array}$ \\
\hline SIMKU & $\begin{array}{l}\text { Sistem Informasi } \\
\text { Manajemen Keuangan }\end{array}$ & $\begin{array}{l}\text { Membantu seluruh kegiatan keuangan seperti } \\
\text { proses administrasi penerimaan dan } \\
\text { pengeluaran anggaran. }\end{array}$ \\
\hline SITP & $\begin{array}{l}\text { Sistem Informasi Tata } \\
\text { Persuratan }\end{array}$ & $\begin{array}{l}\text { Pendelegasian tugas dari atasan berupa } \\
\text { disposisi. }\end{array}$ \\
\hline $\begin{array}{l}\text { SIMAK } \\
\text { BMN }\end{array}$ & $\begin{array}{l}\text { Sistem Informasi } \\
\text { Manajemen dan Akuntansi } \\
\text { BarangMilik Negara }\end{array}$ & Mengelola barang milik negara \\
\hline Website & www.batan.go.id & Diseminasi informasi kegiatan BATAN \\
\hline
\end{tabular}

\section{Portofolio Aplikasi Saat Ini (Data \\ Tahun 2012)}

Portofolio aplikasi saat ini (data tahun 2012), terdapat dua kategori aplikasi, yaitu key operational dan support, sesuai dengan Matriks McFarlan (Ward and Peppard, 2002). Aplikasi SI yang termasuk dalam kategori key operational, yaitu: perpustakaan online, jurnal online, website BATAN, website Nuclear Health Center, website info nuklir, Sistem Informasi Pusdiklat, Sistem Informasi Penelaahan Litbangyasa, dan e-learning. Sedangkan aplikasi SI yang termasuk kategori support, antara lain: Sistem Informasi Tata Persuratan, Sistem Informasi Penatausahaan dan Pelaporan Anggaran, Sistem Informasi Absensi Pegawai, aplikasi perkantoran, SIRA, LPJ bendahara online, Sistem Informasi Kepegawaian, dan SIMAK BMN.

\section{Kondisi SI/TI Saat Ini}

Saat ini (data tahun 2012), data-data yang digunakan di lingkungan BATAN, yaitu data kepegawaian, data keuangan, data penelitian, data Nuclear Health, data pembelajaran nuklir, dan data pelatihan.

\section{Landscape Aplikasi Saat Ini}

Landscape Aplikasi pada BATAN saat ini (data tahun 2012), seperti dapat dilihat pada gambar 9, terdapat portal web sebagai pintu gerbang akses ke sistem informasi lainnya. Sistem informasi yang digunakan yaitu disposisi otomatis, sistem informasi penatausahaan dan pelaporan anggaran, SIAPP, SIPL, SIPPA, SIRA, SITP, perpustakaan online, SISFO Pusdiklat, jurnal online, dan Sistem Informasi Kepegawaian. Belum digunakan sistem online untuk penelitian dan kemitraan.

\section{Perspektif Aplikasi BATAN}

Perspektif aplikasi BATAN dapat dilihat pada gambar 10, ditinjau dari perspektif TOGAF. Portal web merupakan layanan user interface. Relational Data Base Management System (RDBMS) yang digunakan merupakan salah satu layanan data interchange. 


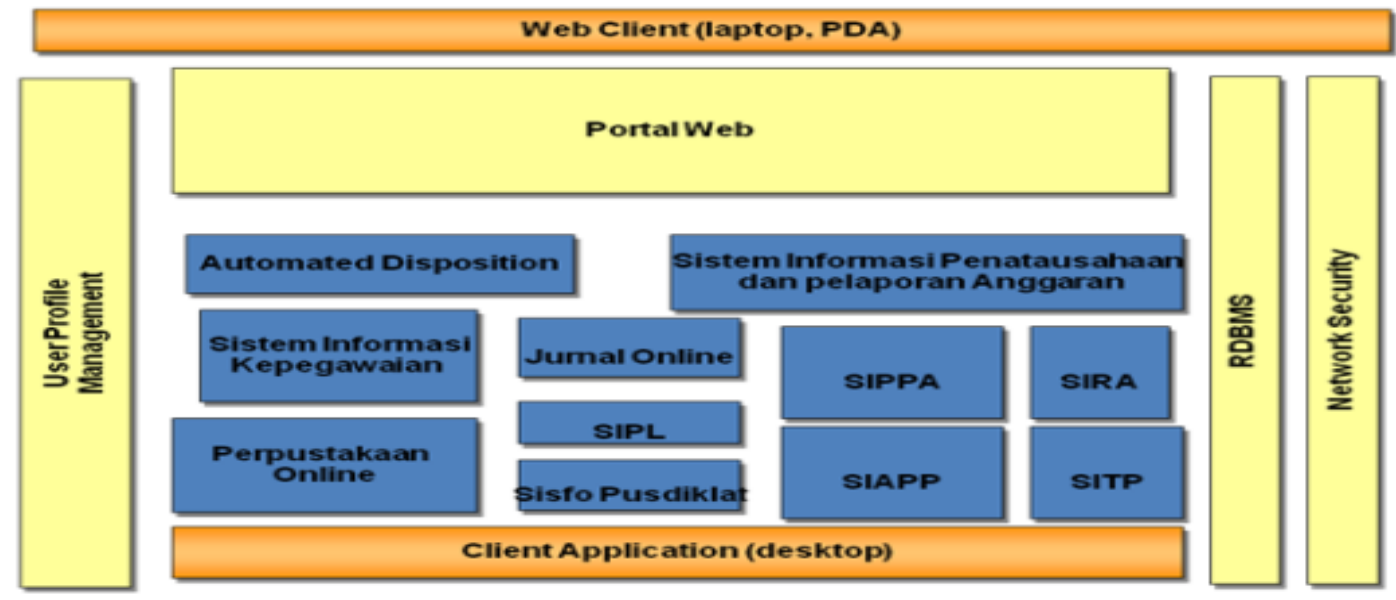

Gambar 9. Landscape Aplikasi Saat Ini (data tahun 2012)

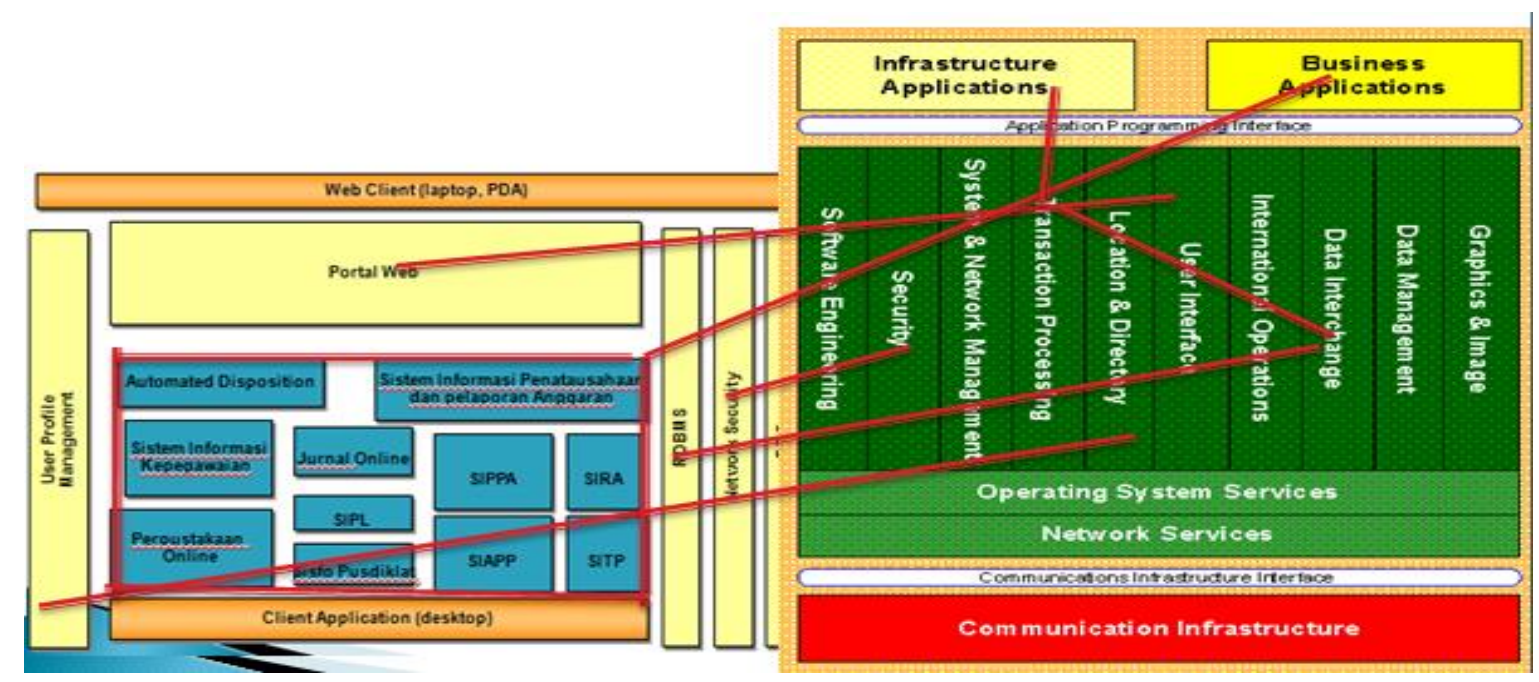

Gambar 10. Perspektif Aplikasi BATAN

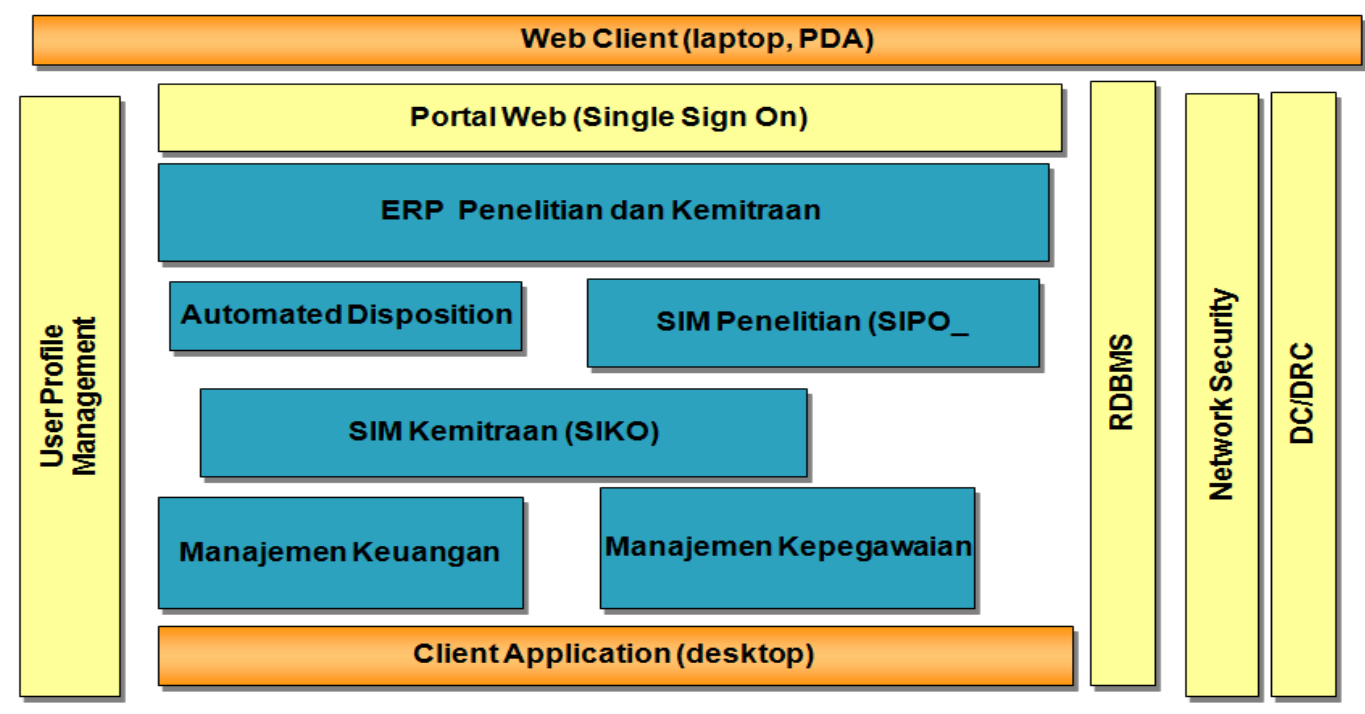

Gambar 11. Landscape Aplikasi Mendatang 


\section{Landscape Aplikasi Mendatang}

Gambar 11, menunjukkan landscape aplikasi BATAN mendatang (usulan). Diusulkan untuk menambahkan dan menggabungkan beberapa sistem informasi sesuai dengan kebutuhan bisnis BATAN. Aplikasi yang diusulkan untuk ditambahkan atau digabungkan, yaitu Sistem Informasi Manajemen (SIM) kepegawaian, SIM keuangan, SIM kemitraan, SIM penelitian, dan Enterprise Resource Planning (ERP) Penelitian dan Kemitraan.

\section{Infrastruktur Saat Ini}

Terdapat beberapa perangkat yang digunakan, antara lain router, leased line, server (belum ada pusat data), firewall, NOC, dan FO. Sistem informasi yang digunakan belum terintegrasi, belum terdapat mekanisme sharing infrastruktur dan pengelolaan bandwidth (data tahun 2012).

\section{Infrastruktur Ideal}

1. Sistem informasi yang sebelumnya belum terintegrasi sehingga perlu diintegrasikan, terutama sistem informasi yang mendukung proses bisnis utama; sementara sesuai strategi SI/TI diperlukan integrasi data dan integrasi aplikasi;
2. Perangkat lunak yang digunakan idealnya mendukung open standar sehingga masih dapat digunakan dalam pengembangan dan integrasi sistem yang memerlukan software tersebut;

3. Sistem informasi yang ada belum terintegrasi datanya dalam suatu DC/DRC, sehingga perlu adanya investasi terkait DC/DRC;

4. Hal yang perlu diperhatikan dari sistem informasi yang online adalah aspek keamanan (security). Oleh karena itu harus dipertimbangkan bagaimana pemenuhan security tersebut, apakah akan dibangun sendiri atau melalui jasa outsourcing;

5. Manajemen jaringan yang efisien dan alokasi penggunaan bandwidth sehingga tidak terjadi overload bandwidth akibat adanya salah satu unit kerja yang tidak mengkonfirmasikan penggunaan bandwidth;

6. Pengembangan dan integrasi sistem dapat dilakukan dengan outsourcing atau swakelola;

7. Perlu dibuat Disaster Recovery Center (DRC) yang berfungsi sebagai fasilitas untuk menanggulangi kerusakan sistem akibat bencana alam atau kejadian tak terduga, sehingga diperlukan backup dan mirror sistem.

\begin{tabular}{|c|c|c|c|c|c|c|c|c|}
\hline & \multicolumn{7}{|c|}{ FUTURE } \\
\hline & & Website & SITP & $\begin{array}{l}\text { SIM } \\
\text { Kepegawai } \\
\text { an }\end{array}$ & $\begin{array}{l}\text { ilM } \\
\text { Keuangan }\end{array}$ & $\begin{array}{l}\text { SIMAK } \\
\text { BMN }\end{array}$ & SIPO & SIKO \\
\hline \multirow{9}{*}{ Eksisting } & $\begin{array}{l}\text { Website, } \\
\text { jurnal online } \\
\text { e-learning }\end{array}$ & $\begin{array}{l}\text { Retain } \\
\text { (Integrate) }\end{array}$ & & & & & & \\
\hline & SITP & & Retain & & & & & \\
\hline & SIPL & & & & & & Replace & \\
\hline & SIPPA & & & & Replace & & & \\
\hline & $\begin{array}{l}\text { SIRA, LPJ } \\
\text { Online }\end{array}$ & & & & Replace & & & \\
\hline & SIK, SIAPP & & & Replace & & & & \\
\hline & SIMAK BMN & & & & & Retain & & \\
\hline & SIP & & & Repalce & & & & \\
\hline & BARU & & & & & & Add & Add \\
\hline
\end{tabular}

Gambar 12. Tabulasi TOGAF untuk Kesenjangan Sistem Informasi 


\begin{tabular}{|c|c|c|c|c|c|c|c|}
\hline & \multicolumn{6}{|c|}{ FUTURE } \\
\hline & & J2EE & ORACLE & $\begin{array}{l}\text { Appache } \\
\text { Web } \\
\text { Server }\end{array}$ & Java Script & \begin{tabular}{|l} 
Linux \\
RedHat
\end{tabular} & SOAP \\
\hline \multirow{7}{*}{ Eksisting } & PHP & Replace & & & & & \\
\hline & My SQL & & Replace & & & & \\
\hline & $\begin{array}{l}\text { Appache } \\
\text { Web Server }\end{array}$ & & & Retain & & & \\
\hline & Java Script & & & & Retain & & \\
\hline & \begin{tabular}{|l} 
Server \\
FreeBSD
\end{tabular} & & & & & Replace & \\
\hline & $\begin{array}{l}\text { Windows } \\
\text { Server } 2008\end{array}$ & & & & & Replace & \\
\hline & BARU & & & & & & Add \\
\hline
\end{tabular}

Gambar 13. Tabulasi TOGAF untuk Kesenjangan Infrastruktur TI

Tabulasi TOGAF untuk Kesenjangan Sistem Informasi

Tabulasi TOGAF untuk kesenjangan sistem informasi BATAN dapat dilihat pada gambar 12. Aplikasi yang diusulkan untuk dipertahankan (retain) yaitu: website, jurnal online, e-learning, SITP, dan SIMAK BMN. Sistem Informasi Penelitian Online (SIPO) dan Sistem Informasi Kemitraan Online (SIKO) merupakan sistem informasi baru (add) yang diusulkan.

\section{Tabulasi TOGAF untuk Kesenjangan Infrastruktur TI}

Tabulasi TOGAF untuk kesenjangan infrastruktur TI BATAN dapat dilihat pada gambar 13. Infrastruktur TI yang diusulkan untuk dipertahankan (retain) yaitu: Apache Web Server dan Java Script. SOAP merupakan infrastruktur TI baru ( $a d d)$ yang diusulkan.

\section{Diskusi}

Sistem informasi yang penting dan tidak tumpang tindih di BATAN yang perlu dipertahankan antara lain website, jurnal online, e-learning, SITP, dan SIMAK BMN. Sistem informasi di BATAN ada yang masih tumpang tindih fungsinya dengan aplikasi lain sehingga perlu untuk diintegrasikan seperti SIK dan SIAPP diganti dengan SI Kepegawaian, aplikasi
SIPPA, SIRA, dan LPJ Online diganti dengan SIM Keuangan. Selain aplikasi tersebut, untuk memenuhi kebutuhan dan memerlancar kinerja di BATAN perlu dibangun Sistem Informasi Penelitian Online (SIPO) dan Sistem Informasi Kemitraan Online (SIKO).

Dengan adanya Sistem Informasi Penelitian Online (SIPO) ini diharapkan pelaksanaan penelitian menjadi lebih mudah dari proses pengajuan judul, pengajuan proposal, persetujuan penganggaran, monitoring pelaksanaan penelitian, penyerahan laporan, sampai dengan publikasi hasil-hasil penelitiannya kepada publik. Sistem Informasi Kemitraan Online (SIKO) yang diusulkan untuk dibangun diharapkan memberikan kemudahan kepada mitra BATAN untuk melakukan kerjasama baik dalam hal penelitian, publikasi hasil-hasil penelitian, ataupun sosialisasi program-program kerja dengan BATAN.

Dari hasil analisis kesenjangan infrastruktur menunjukkan bahwa Apache Web Server dan Java Script merupakan infrastruktur yang sebaiknya dipertahankan. Hal ini karena Apache Web Server adalah software gratis yang mudah diinstal, bisa beroperasi di berbagai platform sistem operasi, aman dan mudah menambahkan peripheral lainnya. Kelebihan dari Java Script adalah tidak 
membutuhkan resource memory yang besar, multiplatform yang bisa dijalankan di banyak sistem operasi, dinamis, dan mudah untuk dikembangkan. SOAP diusulkan karena dapat digunakan di berbagai sistem operasi dan mudah digunakan karena memanfaatkan berbagai teknologi yang sudah ada dan banyak digunakan.

\section{PENUTUP}

\section{Simpulan}

Sistem Informasi website, jurnal online, e-learning, SITP, dan SIMAK BMN merupakan aplikasi yang dipertahankan. Aplikasi SIK dan SIAPP diganti dengan SI Kepegawaian, aplikasi SIPPA, SIRA, dan LPJ Online diganti dengan SIM Keuangan. Aplikasi yang perlu ditambahkan adalah Sistem Informasi Penelitian Online (SIPO) dan Sistem Informasi Kemitraan Online (SIKO). Infrastruktur TI yang dipertahankan adalah Apache Web Server dan Java Script. Infrastruktur baru yang perlu ditambahkan adalah SOAP. Infrastruktur TI yang perlu diganti antara lain PHP diganti dengan J2EE, MySQL diganti dengan ORACLE, Server Free BSD dan Windows Server diganti dengan Linux RedHat.

\section{Saran}

Sebaiknya BATAN melakukan perbaikan berdasarkan hasil penelitian agar proses bisnis berjalan lebih efektif dan efisien. Aplikasi-aplikasi yang ada sebaiknya diganti, ditambah, ataupun dipertahankan.

\section{DAFTAR PUSTAKA}

Anggrainingsih, R., Aprianto, G. R. and Sihwi, S. W. (2013). Arsitektur Bisnis Biro Administrasi Kemahasiswaan (AK) Pada Perancangan Arsitektur Enterprise Universitas Sebelas Maret Menggunakan Framework TOGAF. In: SEMINAR NASIONAL TEKNOLOGI INFORMASI
\& KOMUNIKASI TERAPAN 2013 (SEMANTIK 2013), 2013, Semarang: Universitas Dian Nuswantoro, p.317324.

Kasim, A. (1995). Teori Pembuatan Keputusan. Jakarta: Lembaga Penerbit Fakultas Ekonomi Universitas Indonesia.

Kustiyahningsih, Y. (2013). PERENCANAAN ARSITEKTUR ENTERPRISE MENGGUNAKAN METODE TOGAF ADM (STUDI KASUS : RSUD Dr.SOEGIRI LAMONGAN). In: Prosiding Seminar Nasional Manajemen Teknologi XVIII, 2013, Surabaya: Program Studi MMT-ITS.

Robertson, B. and Sribar, V. (2002). The Adaptive Enterprise: IT Infrastructure Strategies to Manage Change and Enable Growth. Intel Press IT Best Practices Series.

Rosalina, V., Sugiyani, Y. and Triayudi, A. (2014). Perancangan Infrastruktur Jaringan Komputer dalam Konsep Membangun Serang Menuju Smartcity. Jurnal Sistem Komputer, 1 (1).

Solichin, A. and Hasibuan, Z. A. (2012). PEMODELAN ARSITEKTUR TEKNOLOGI INFORMASI BERBASIS CLOUD COMPUTING UNTUK INSTITUSI PERGURUAN TINGGI DI INDONESIA. In: Seminar Nasional Teknologi Informasi \& Komunikasi Terapan 2012 (Semantik 2012), 2 (1), 2012, Semarang: Universitas Dian Nuswantoro, p.10-16.

The Open Group Architecture Forum. (2011). TOGAF® Version 9.1, Enterprise Edition.

The Stationery Office. (2011). ITIL® Service Design. 2nd ed. The Stationery Office.

Ward, J. and Peppard, J. (2002). Strategic Planning for Information System. 3rd ed. John Wiley and Sons.

Wibowo, F. G., Nugroho, E. and Winarno, W. W. (2013). Perancangan Model Sistem Otomatisasi Pengajuan Angka Kredit Dengan Menggunakan TOGAF Architecture Development Method (Studi Kasus: Badan Pemeriksa Keuangan RI). Studi Informatika: Jurnal Sistem Informasi, 6 (1), p.1-12. 